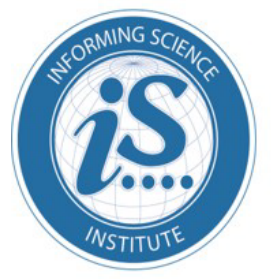

Interdisciplinary Journal of Information, Knowledge, and Management

An Official Publication

of the Informing Science Institute

InformingScience.org

IJIKM.org

Volume 13, 2018

\title{
THE MECHANISM OF INTERNET CAPABILITY DRIVING Knowledge Creation Performance: THE EFFECTS OF STRATEGIC FLEXIBILITY AND INFORMATIZATION DENSITY
}

\begin{tabular}{ll}
\hline Caiyun Zhuang & $\begin{array}{l}\text { School of Economics and Management, } \\
\text { Fuzhou University, Fuzhou, P.R. China }\end{array}$ \\
Guohong Chen* & $\begin{array}{l}\text { School of Economics and Management, } \\
\text { Fuzhou University, Fuzhou, P.R. China }\end{array}$ \\
Jian Hou & School of Economics and Management, \\
& Harbin Engineering University, Harbin, \\
& P.R. China \\
Juan Liang & School of Business \\
& Jiangxia University, Fuzhou P.R. China
\end{tabular}

*Corresponding author

\begin{abstract}
Aim/Purpose This study analyzes the mechanism of Internet capability (IC) driving knowledge creation performance (KCP). We consider the mediating role of strategic flexibility and the moderating role of informatization density.

Background The key to achieving KCP for firms is to transform knowledge created into new products or services and to realize the economic benefits. However, the research has not paid enough attention to firms' KCP. Based on dynamic capability theory, this study empirically reveals how firms drive KCP through Internet capability.

Methodology The study uses survey data from 399 organizations in China. Through structural equation modeling, this study assesses the relationship between Internet capability, strategic flexibility, and KCP and uses hierarchical regression to test the moderating role of informatization density.
\end{abstract}

Accepted by Editor Dale Trott | Received: April 17, 2018 | Revised: June 26, July 4, July 10, July 17, August 1, 2018 | Accepted: August 22, 2018.

Cite as: Zhuang, C., Chen, G., Hou, J., \& Liang, J. (2018). The mechanism of internet capability driving knowledge creation performance: The effects of strategic flexibility and informatization density. Interdisciplinary Journal of Information, Knowledge, and Management, 13, 259-278. https://doi.org/10.28945/4108

(CC BY-NC 4.0) This article is licensed to you under a Creative Commons Attribution-NonCommercial 4.0 International License. When you copy and redistribute this paper in full or in part, you need to provide proper attribution to it to ensure that others can later locate this work (and to ensure that others do not accuse you of plagiarism). You may (and we encourage you to) adapt, remix, transform, and build upon the material for any non-commercial purposes. This license does not permit you to use this material for commercial purposes. 
Contribution First, this study expands research on knowledge creation and focuses on the further achievement of knowledge creation performance. The study also enriches the exploration of KCP in the Internet context and deepens the research on the internal mechanism by which Internet capability influences KCP. Second, this study highlights the important role of informatization density in the Internet context and expands the research on the impact of external factors on the internal mechanism.

Findings First, Internet capability has a significantly positive effect on both strategic flexibility and KCP. Furthermore, Internet capability directly impacts strategic flexibility, yet it affects KCP both directly and indirectly through strategic flexibility, which confirms that strategic flexibility is a partial mediator in the relationship between Internet capability and KCP. Second, strategic flexibility positively influences KCP. Third, informatization density has a significant moderating effect on the relationship between Internet capability and KCP.

Recommendations The results indicate that firms should consider the importance of Internet for Practitioners capability and strategic flexibility for KCP in the Internet context. This study also provides a theoretical basis that could guide the Chinese government's informatization construction of the industrial chain.

Recommendations Researchers could further explore the role of other mediator variables (e.g., for Researchers business process management, organizational agility) and consider the role of other moderator variables (e.g., resource commitment, learning orientation).

Impact on Society This study provides a reference for enterprises with similar cultural backgrounds in using Internet capability to enhance their competitive advantage.

Future Research Future research could collect data from various countries and regions to test the research model and conduct longitudinal studies to increase the robustness of the conclusions.

Keywords Internet capability, knowledge creation performance, strategic flexibility, informatization density

\section{INTRODUCTION}

Creating new knowledge to adapt to today's turbulent environment characterized by "time-based competition" is an important challenge for firms amid the rapid development of science and technology and the rapid change in consumption demand (M. Li, Liu, \& Zhou, 2018). Transforming the knowledge created into products and services and improving knowledge-creation efficiency is key to acquiring and maintaining competitive advantage (Cai, 2015). In recent years, the innovation-driven development strategy advocated by the Chinese government has focused on technological innovation and achievement transformation, providing strong policy support for the achievement of knowledge creation performance (KCP) (Jiang, Mu, \& Zhou., 2017). The KCP process involves the allocation of resources related to knowledge creation, such as personnel, funds, and information, to achieve the transforming performance of resource input and knowledge output (H. Chen \& Hou, 2017). The focus of the KCP is on "creating and applying" and transforming the knowledge created into new products or services to realize the economic benefits. However, the research has paid little attention to the KCP of firms. Some studies consider social networking mode, dynamic capability, technical factors, the environment, and other internal and external factors influencing the KCP of firms (C. J. 
Chen, Chang, \& Hung, 2011; Kao \& Wu, 2016; Park \& Ryu, 2015; Schneckenberg, Truong, \& Mazloomi, 2015). However, these studies rarely pay attention to how firms enhance KCP in the Internet context. This study focuses on that question. Based on dynamic capability ${ }^{1}$, it reveals how firms drive KCP through their Internet capability.

Chinese firms are operating in a transition economy, and their external environment is becoming more complex and unpredictable. The worldwide technological revolution and the acceleration of technological innovation have aggravated the instability of the business environment. Meanwhile, the rapid development of the Internet in China has brought opportunities for firms. Amid this environment, Chinese firms' decision-making processes need a dynamic strategy and an Internet-based mindset. Internet capability reflects the ability of an organization to acquire, deploy, and configure Internet resources ${ }^{2}$ to support and improve their business strategies and work processes. It is critical for firms to create a strategic value to acquire sustainable competitive advantage (Bharadwaj, 2000; Ross, Beath, \& Goodhue, 1996). Liao, Kickul, and Ma (2009) pointed out that, to survive in a highly competitive Internet environment, firms must find ways to move beyond their current resource base. The competitive advantage of a firm stems from the Internet capability to constantly update and redeploy corporate resources. Joshi, Chi, Datta, and Han (2010) noted that Internet capability helps firms establish social capital; promote seamless network connections among firms, which speeds up firms' knowledge sharing and creation; and promote the commercialization of innovations. In addition, firms with strong Internet capability often have a strong strategic flexibility, allowing them to identify changes in the environment in a timely way and make adjustments (Celuch, Murphy, \& Callaway, 2007), thus overcoming any potential resistance to KCP achievement (Jiang et al., 2017). Therefore, exploring the influence of strategic flexibility on the relationship between Internet capability and KCP is particularly important. However, the research seldom examines these factors in the same research framework.

The traditional resource-based view (RBV) and knowledge-based view (KBV) tend to focus on the internal organizational mechanism's role in enhancing firm performance, while ignoring the role of the external mechanism (Mao, Liu, \& Zhang, 2015). Research has shown the necessity of integrating external factors and internal mechanisms in a comprehensive analysis (Y. Chen et al., 2014; Mao et al., 2015). We know from contingency theory that successful organizations can find a conjunction between environment and organizational structures and take advantage of potential opportunities (Umanath, 2003). In the research on Internet capability and organizational performance, certain contextual factors, such as industry type, environmental factors, information intensity ${ }^{3}$, and competitive intensity, ${ }^{4}$ have been found to be potential moderators (Bhatt, 2000; Y. Chen et al., 2014; Mao et al., 2015; Prajogo, 2016). However, the moderating effect of informatization density ${ }^{5}$ in the Internet context is rarely considered. The rapid development of information technology has directed more research attention to the industrial informatization process. Thus, this study integrates the internal and external factors of the firm and examines the moderating role of informatization density be-

1 Dynamic capability refers to the ability of a firm to integrate, create, and reconstruct its internal and external competitiveness to adapt to changing circumstances.

2 Internet resources refer to the physical capital, human capital, and organizational capital used to realize Internet value.

3 Information intensity refers to the amount of information that must be acquired and processed through value chains and customers.

4 Competitive intensity refers to the extent to which fragmented and fierce competition poses a threat to firms due to resource scarcity and tighter profit margins.

5 Informatization density is defined as the proportion of informatization input in production activities. 
tween Internet capability and KCP. This study is trying to bridge the gaps described above by addressing three research questions:

1) How does Internet capability affect KCP?

2) Does strategic flexibility play a mediating role in the relationship between Internet capability and KCP?

3) Does informatization density enhance KCP and strengthen the effect of Internet capability on KCP?

The rest of this paper is organized as follows. A conceptual background is presented in the next section, and the study's hypotheses and research model are developed in the third section. Then, the study's research methodology is explained. The fifth section provides the analysis results and the findings obtained through structural equation modeling and hierarchical regression analysis. The theoretical and managerial implications of our findings are discussed in the section that follows. Finally, we offer concluding remarks.

\section{CONCEPTUAL BACKGROUND}

\section{INTERNET CAPABILITY}

In line with the RBV, Internet capability is regarded as the key factor for gaining sustainable competitive advantage (Bharadwaj, 2000; Ross et al., 1996; Wade \& Hulland, 2004). In this study, Internet capability is defined as an organization's ability to acquire, deploy, combine, and reconfigure Internet resources to support and improve business strategy and workflow (Bharadwaj, 2000; Mao et al., 2015; Ross et al., 1996). Scholars have proposed various ways to understand Internet capability and have divided it into different dimensions (Bhatt, 2000; Mao et al., 2015; Ross et al., 1996; Wade \& Hulland, 2004). It is generally understood that Internet capability is not only a technological capability but also an organizational capability that reflects the combination of Internet and associated resources and capabilities within the firm. Lu and Ramamurthy (2011) provide an integrated multi-dimensional research framework, which is regarded as representative of organizational practices, covering the quality of firms' Internet resources and resource management ability.

Therefore, we will follow Lu and Ramamurthy (2011) by categorizing Internet capability into Internet infrastructure capability, Internet business spanning capability, and Internet proactive stance. Of these three dimensions, Internet infrastructure capability refers to a firm's ability to deploy shared platforms, reflecting a firm's capability in data management services and architectures, network communication services, and application composition and services (Lu \& Ramamurthy, 2011; Mao et al., 2015; Weill, Subramani, \& Broadbent, 2002). Internet business spanning capability is the firm's ability to find and utilize Internet resources to support and enhance business objectives. It demonstrates firms' strategic Internet vision, integrating business and Internet strategic planning. It also reflects that firms have a clear understanding of the Internet's investment value (Lu \& Ramamurthy, 2011; Mao et al., 2015; Weill et al., 2002). Internet proactive stance is defined as the ability to develop new Internet innovation or to explore the available Internet resources to create and use business opportunities and competitive advantages (Lu \& Ramamurthy, 2011; Mao et al., 2015; Weill et al., 2002). Internet proactive stance measures the organization's attitude to Internet innovation and the value of the Internet. Considering that this study focuses on Internet capability, we follow the practice of Lu and Ramamurthy (2011) by regarding Internet capability as a second-order structure and examine its impact on an integration level. Internet infrastructure capability, Internet business spanning capability, and Internet proactive stance are three first-order dimensions of Internet capability. 


\section{STRATEGIC FLEXIBILITY}

Strategic flexibility was first proposed by Ansoff (1965) and then received widespread scholarly attention. The strategic flexibility concept emphasizes that firms should be able to cope with potential opportunities or threats in an unstable or unpredictable environment in active and passive ways, so as to effectively control risks and uncertainties to enhance organizational competitive advantage $(\mathrm{H}$. B. Zhang, 2015). Schneider and Spieth (2014) contended that strategic flexibility is essentially a kind of management ability, with the characteristics of management diversification and quick response. Scholars have noted that strategic flexibility is dualistic, embodying both the ability of a firm to "preemptively" take the initiative to predict the future environment as well as the rapidity and effectiveness of a firm's response to environmental changes (Evans, 1991; Johnson, Lee, Saini, \& Grohmann, 2003). This view is consistent with the standpoint in the Internet technology literature (Celuch et al., 2007). Specifically, Internet capability promotes knowledge flow, information flow, and organization learning, helping businesses proactively predict potential future changes. At the same time, Internet capability helps firms monitor and coordinate the relationship between internal and external stakeholders and provides timely access to intelligence on change in the external environment, which enables firms to quickly and effectively respond to environmental changes (Johnson et al., 2003).

\section{INFORMATIZATION DENSITY}

The rise and rapid development of information technology affects the organizational forms of firms and all aspects of business operations and management (Volkoff, Strong, \& Elmes, 2007). The informatization of enterprises is receiving more attention (Bayo-Moriones, Billón, \& Lera-López, 2013; Becchetti, Bedoya, \& Paganetto, 2003; Bharadwaj, 2000). Scholars have pointed out that firms invest significantly in information technology to cope with environmental changes every year; investments target areas such as communications, product development, marketing, and data analysis (Yu, Jacobs, Chavez, \& Feng, 2017). Informatization density is defined as the proportion of informatization input in production activities. When the informatization density is higher, levels of informatization and intelligentization ${ }^{6}$ in production links are also higher (Becchetti et al., 2003; K. W. Li, Shao, \& Wang, 2015). Therefore, this study draws from the division criteria of the industry value chain used by the World Bank investigation team, and uses the usage frequency of information technology in every link of the industrial chain as a proxy variable for informatization density. Related studies, such as B. Li and Liang (2017), Liu (2016), Yang and Wang (2017), which used empirical data on Chinese firms, also used these criteria to measure informatization density. We thus define informatization density as the degree of application and dependence on information technology in all aspects of the industrial chain. It can be measured as the usage frequency of information technology in every link of the industrial chain (Li \& Liang, 2017; Liu, 2016; Yang and Wang, 2017). The higher the informatization density, the greater the access to knowledge, information, and technology in all aspects of the industrial chain and the greater the frequency of communication among firms. This promotes knowledge sharing and establishes the external conditions that enable firms to acquire knowledge, share knowledge, communicate with each other, and create knowledge, thus laying a foundation for the promotion of KCP (Yang \& Wang, 2017).

6 Intelligentization refers to the attributes that things can dynamically meet the various needs of people, supported by technologies such as the Internet, big data, the Internet of Things, and artificial intelligence. 


\section{HYPOTHESES}

\section{INTERNET CAPABILITY AND KNOWLEDGE CREATION PERFORMANCE}

According to the KBV, the competitive advantage of a firm derives from the acquisition, creation, and application of knowledge and the added value of products and services (Martin-de Castro, Lopez-Saez, \& Delgado-Verde, 2011). Internet capability is the core competency that effectively promotes the acquisition, sharing, creation, transformation, and utilization of knowledge. Discussing the Internet infrastructure capability dimension, Kane and Alavi (2007) noted that employees can share and transfer new knowledge through an interactive network community, video conferencing, and other Internet technology applications, which will enhance the flow and transformation of new knowledge. Lee and Lim (2005) argued that firms can analyze and integrate new and old knowledge by using knowledge warehouses, databases, and other IT applications. Discussing the Internet business spanning capability dimension, Lu and Ramamurthy (2011) pointed out that the synergy between the Internet and business activities has ensured rapid and efficient responses to organizations' external innovation, especially for innovative activities that require fundamental changes to business processes and information systems. Research based on the Marshall industrial case showed that collaboration between IT and business managers could be essential to continuous IT-based innovation (Lu \& Ramamurthy, 2011). In terms of the Internet proactive stance dimension, Gulati, Nohria, and Zaheer (2000) contended that using a global information network enables organizations to proactively access information about product prices, innovation trends, and other data. The proactive stance enables organizations to identify market opportunities and quickly exploit them to promote KCP (Glavas \& Mathews, 2014). Thus, the following hypothesis is proposed:

$\mathrm{H} 1$ : Internet capability is positively related to KCP.

\section{INTERNET CAPABILITY AND STRATEGIC FLEXIBILITY}

Internet capability is a powerful weapon for enhancing the strategic flexibility of the organization (Y. J. Wang, Xie, \& Lan, 2012). Hatch and Zweig (2001) indicated that the ability of a firm to survive and develop is based on its ability to realize the match between the external environment and internal resources by "amending its competitive position, adjusting its value proposition, and rapidly sensing changes in the external environment." Further, Sambamurthy, Bharadwaj, and Grover (2003) argued that firms need to use Internet technology to cope with a complex and changeable market and engage in the development, aggregation, and dissemination of product and process information to gain a foothold in a highly competitive business environment. Some scholars have discussed the strategic role of the Internet from the perspective of dynamic capability and have argued that Internet capability can serve as a resource with which firms can build dynamic capability related to sustainable competitive advantages (such as strategic flexibility) to foster long-term business success (Teece, 2007). Lu and Ramamurthy (2011) argued that superior Internet infrastructure ensures the standardization and integration of data and provides firms with a global integration platform that enables them to gather and share knowledge instantly, accurately, and comprehensively, thereby enhancing the effectiveness of their decision-making and strategic flexibility (Mao, Liu, Zhang, \& Deng, 2016). Internet business spanning capability emphasizes the integration of strategy and Internet planning, as well as the synergy of the Internet and business processes (Wade \& Hulland, 2004). The design of information systems for the target business process can enable the knowledge and information of each business process to reach the required business units, which increases communication and decision efficiency within the organization and enhances its strategic flexibility. In addition, organizations that gain a more comprehensive understanding of the commercial value of the Internet can reduce 
their resistance to change in a turbulent environment and enhance their strategic flexibility. An Internet proactive stance also enables organizations to seek Internet-enabled innovation, which provides them with a variety of options for responding to changes in the external environment (Mao et al., 2015). Thus, the following hypothesis is proposed:

H2: Internet capability is positively related to strategic flexibility.

\section{STRATEGIC FLEXIBILITY AND KNOWLEDGE CREATION PERFORMANCE}

Most researchers have verified the positive effect of strategic flexibility on firms' innovation performance and have pointed out that strategic flexibility can help firms identify and satisfy customer needs, create higher customer value, and enhance market competitiveness (Hatch \& Zweig, 2001; T. Wang \& Jia, 2011). On the one hand, firms with strong strategic flexibility can allocate and utilize resources more rationally and make better use of externally acquired knowledge and resources (Ceccagnoli \& Hicks, 2013), thereby promoting KCP. Strategic flexibility also allows firms to proactively predict and tap markets with high potential and high growth (Celuch et al., 2007), an important prerequisite for transforming their knowledge creation into products or services for economic value. On the other hand, the basic process of KCP achievement requires firms to make full use of their workforce, knowledge, and technical resources to transform created knowledge into products or services and push them into the market to become commodities, and thus gain recognition through market competition to create economic and social value. The external environment in the Internet context is relatively complex and dynamic. The achievement of KCP requires dynamic strategic thinking and action. The success of the series of necessary processes-from knowledge creation to products and services to commodities — cannot be separated from the support of firms' strategic flexibility (Jiang et al., 2017). Thus, the following hypothesis is proposed:

H3: Strategic flexibility is positively related to KCP.

\section{MEDIATING ROLE OF STRATEGIC FLEXIBILITY}

Strategic flexibility is widely recognized as the key to gaining competitive advantage and improving performance in the twenty-first century (Cingöz \& Akdoğan, 2013). As a typical dynamic capability, strategic flexibility can be regarded as the ability of a firm to allocate resources, which possesses the basic characteristics of organizational capability. Therefore, strategic flexibility should be based on information and serve as the mediator between resources and competitive advantage (Lin \& Zhao, 2013). Scholars studying resources have pointed out that strategic flexibility based on information systems is conducive to enhancing the market competitiveness of firms (M. J. Zhang, 2005). On one hand, Internet capability can help firms obtain market information effectively, allowing them to understand the changes in the external environment and allocate internal and external resources in a timely way, which enhances strategic flexibility. This is a prerequisite for the achievement of KCP. On the other hand, firms with strong Internet capability are good at using Internet resources to promote internal and external knowledge flow and coordinate internal and external social capital, which helps them predict and perceive possible changes (Celuch et al., 2007) and fosters the achievement of KCP. In addition, firms with a clear understanding of the potential value of the Internet can promote the utilization of Internet innovation and combine their Internet strategy with their organizational business strategy (Mao et al., 2015), thus enhancing their strategic flexibility and allowing them to overcome any potential resistance to KCP. Thus, the following hypothesis is proposed:

H4: Strategic flexibility mediates the relationship between Internet capability and KCP. 


\section{MODERATING ROLE OF INFORMATIZATION DENSITY}

Most studies have affirmed the positive impact of Internet technology on enterprises (BayoMoriones et al., 2013; Becchetti et al., 2003; Bharadwaj, 2000). Studies such as Yang and Wang (2017) have confirmed that the informatization density of the industrial chain has a positive impact on the tendency to form R\&D alliances. Information technology has a greater role in promoting industrial growth in industries with high informatization density (B. Li \& Liang, 2017). K. W. Li et al. (2015) pointed out that firms with high informatization density tend to choose exports. Obviously, the research on informatization regards it as an influential factor in performance, but it needs to be further studied as a moderator. Informatization density reflects the degree of the informatization of all links in the industrial chain. First, when the informatization density is high, firms can acquire information, technology, and knowledge from each link of the industrial chain through Internet-based or knowledge-based platforms and channels, which will improve the organization's ability to acquire information (Mao et al., 2015) and lay a foundation for the achievement of KCP. Second, when informatization density is high, organizations are more likely to develop a high level of Internet capability to adapt to the informatization of the industrial chain, thereby enabling the organization to respond rapidly to market and customer needs (Mao et al., 2015; Yang \& Wang, 2017), which will reinforce the transformation of knowledge into valuable products or services. Third, improvements in informatization density will increase the communication frequency of firms at all levels, enhance knowledge sharing and organizational learning among firms, and foster the achievement of KCP (Yang \& Wang, 2017). Thus, the following hypothesis is proposed:

H5: The positive effect of Internet capability and KCP is moderated by informatization density.

The relationships investigated in this study are presented in Figure. 1.

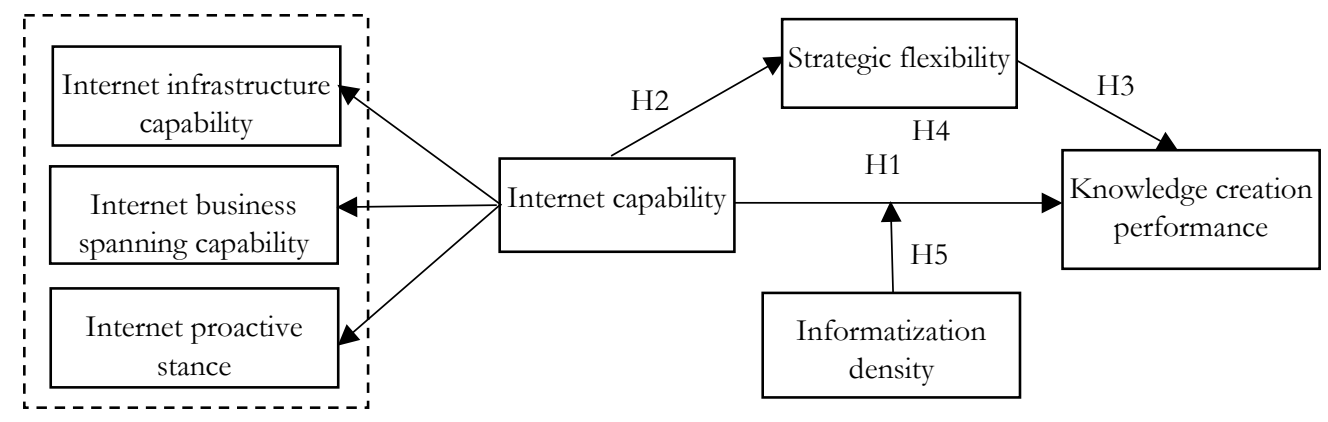

Figure. 1. Our Theory Model

\section{RESEARCH METHODOLOGY}

\section{CONSTRUCT MEASUREMENT}

The measurement items for all the model constructs were adopted from existing research in which the instrument was carefully tested (see Table 1). Consistent with previous studies, we used a fivepoint Likert-type scale to measure the items. The scales for IIC, IBC, IPC, strategic flexibility, informatization density, and KCP range from "strongly disagree" to "strongly agree." Each construct contained at least three items. We conducted a pretest among 10 senior managers to ensure the quality of the questionnaire. We made small modifications based on their suggestions. 
Table 1. Constructs and measures.

\begin{tabular}{|c|c|c|c|c|c|}
\hline Construct & Item & Measurement & $\begin{array}{l}\text { Factor } \\
\text { loading }\end{array}$ & $\begin{array}{l}\text { Cronb- } \\
\text { ach's } \alpha\end{array}$ & Reference \\
\hline \multirow{4}{*}{$\begin{array}{l}\text { Internet } \\
\text { infrastructure } \\
\text { capability }\end{array}$} & IIC & $\begin{array}{l}\text { Data management services and architecture are } \\
\text { sufficient in my organization }\end{array}$ & 0.722 & 0.762 & \multirow{4}{*}{$\begin{array}{l}\text { Lu and } \\
\text { Ramamurthy } \\
\text { (2011); Ross } \\
\text { et al. (1996); } \\
\text { Weil et al. } \\
\text { (2002) }\end{array}$} \\
\hline & & $\begin{array}{l}\text { The network communications can meet the } \\
\text { demand, with good connectivity, reliability, and } \\
\text { availability }\end{array}$ & 0.785 & & \\
\hline & & $\begin{array}{l}\text { Internet applications and service quality (such } \\
\text { as ERP, ASP) can meet organizational needs }\end{array}$ & 0.778 & & \\
\hline & & $\begin{array}{l}\text { Internet technology management services can } \\
\text { effectively manage the relationship between } \\
\text { business units }\end{array}$ & 0.769 & & \\
\hline \multirow{4}{*}{$\begin{array}{l}\text { Internet } \\
\text { business } \\
\text { spanning } \\
\text { capability }\end{array}$} & IBC & $\begin{array}{l}\text { My organization has a clear understanding of } \\
\text { how the Internet can promote competitive } \\
\text { advantage }\end{array}$ & 0.766 & 0.763 & \multirow{4}{*}{$\begin{array}{l}\text { Bhatt (2000); } \\
\text { Lu and } \\
\text { Ramamurthy } \\
\text { (2011) }\end{array}$} \\
\hline & & $\begin{array}{l}\text { My organization combines business strategy } \\
\text { with Internet planning }\end{array}$ & 0.739 & & \\
\hline & & $\begin{array}{l}\text { The relevant functional departments under- } \\
\text { stand the value of Internet investments }\end{array}$ & 0.793 & & \\
\hline & & $\begin{array}{l}\text { My organization encourages the use of the } \\
\text { Internet for corporate innovation and product } \\
\text { innovation }\end{array}$ & 0.760 & & \\
\hline \multirow[t]{4}{*}{$\begin{array}{l}\text { Internet } \\
\text { proactive stance }\end{array}$} & IPC & $\begin{array}{l}\text { The Internet planning process of my organiza- } \\
\text { tion is effective and flexible }\end{array}$ & 0.756 & 0.788 & \multirow{4}{*}{$\begin{array}{l}\text { Lu and } \\
\text { Ramamurthy } \\
\text { (2011); Mao } \\
\text { et al. (2015) }\end{array}$} \\
\hline & & $\begin{array}{l}\text { My organization is able to keep up with new } \\
\text { Internet innovations }\end{array}$ & 0.776 & & \\
\hline & & $\begin{array}{l}\text { My organization often innovatively uses some } \\
\text { new Internet technologies }\end{array}$ & 0.828 & & \\
\hline & & $\begin{array}{l}\text { My organization is constantly looking for new } \\
\text { ways to improve the effectiveness of Internet } \\
\text { use }\end{array}$ & 0.770 & & \\
\hline \multirow[t]{5}{*}{$\begin{array}{l}\text { Strategic } \\
\text { flexibility }\end{array}$} & SF & $\begin{array}{l}\text { My organization always adjusts strategies based } \\
\text { on changing circumstances }\end{array}$ & 0.714 & 0.786 & \multirow{5}{*}{$\begin{array}{l}\text { Bierly and } \\
\text { Chakrabarti } \\
\text { (1996); } \\
\text { Evans } \\
\text { (1991); Fan } \\
\text { and Wu } \\
\text { (2014) }\end{array}$} \\
\hline & & $\begin{array}{l}\text { My organization always adjusts resource alloca- } \\
\text { tion based on changes in the environment }\end{array}$ & 0.739 & & \\
\hline & & $\begin{array}{l}\text { My organization is able to seize the opportuni- } \\
\text { ties brought about by environmental changes }\end{array}$ & 0.772 & & \\
\hline & & $\begin{array}{l}\text { When proposing an innovation strategy, a se- } \\
\text { ries of alternatives is always considered }\end{array}$ & 0.702 & & \\
\hline & & $\begin{array}{l}\text { My organization can quickly adjust production } \\
\text { or service levels to support the needs of market } \\
\text { volatility }\end{array}$ & 0.744 & & \\
\hline \multirow[t]{3}{*}{$\begin{array}{l}\text { Informatization } \\
\text { density }\end{array}$} & ID & $\begin{array}{l}\text { Information technology is frequently used to } \\
\text { contact upstream suppliers }\end{array}$ & 0.770 & 0.734 & \multirow{3}{*}{$\begin{array}{l}\text { Becchetti } \\
\text { etal (2003); } \\
\text { K. W. Li et } \\
\text { al. (2015); } \\
\text { Liu (2016) }\end{array}$} \\
\hline & & $\begin{array}{l}\text { Information technology is frequently used in } \\
\text { products and services }\end{array}$ & 0.753 & & \\
\hline & & $\begin{array}{l}\text { Information technology is frequently used in } \\
\text { marketing and sales }\end{array}$ & 0.808 & & \\
\hline \multirow[t]{4}{*}{$\begin{array}{l}\text { Knowledge } \\
\text { creation } \\
\text { performance }\end{array}$} & KCP & $\begin{array}{l}\text { My organization has the ability to transform } \\
\text { patents and technology secrets into products or } \\
\text { services effectively }\end{array}$ & 0.705 & 0.713 & \multirow{4}{*}{$\begin{array}{l}\text { Kao and Wu } \\
\text { (2016); } \\
\text { Y. Li, Guo, } \\
\text { Liu, \& Li } \\
(2008)\end{array}$} \\
\hline & & Innovative products with high success rate & 0.760 & & \\
\hline & & $\begin{array}{l}\text { In the past five years, the amount of new prod- } \\
\text { ucts in our company has increased. }\end{array}$ & 0.719 & & \\
\hline & & $\begin{array}{l}\text { Our company often launches new products and } \\
\text { services earlier than their counterparts }\end{array}$ & 0.750 & & \\
\hline
\end{tabular}




\section{SAMPLING AND DATA COLLECTION}

To test the research model, we conducted a survey in China. In recent years, the rapid development of China's Internet has profoundly affected all aspects of business management in the country. To compete domestically and internationally, Chinese firms are increasingly depending on the Internet to achieve technological innovation and the transformation of scientific and technological achievements. We used The China Enterprises Directory 2016 to identify potential participants. We randomly selected 1100 firms and invited them to participate in our survey via email and phone calls. The key informants were senior executives of firms who were knowledgeable about the issues being examined in this study, such as Internet capability, strategic flexibility, informatization density, and KCP. A total of 650 questionnaires were issued to senior executives who agreed to participate in the survey. Of these questionnaires, 399 valid questionnaires were recovered, yielding a response rate of $61.38 \%$. The characteristics of the organizations are presented in Table 2 . We checked for nonresponse bias by comparing the basic attributes of the early and late responses in terms of organization size and age. We found no significant differences. Therefore, our sample does not appear to be affected by non-response bias.

To test the impact of a possible common method bias, we conducted Harman's single-factor test by adding all the indicators in a principal components factor analysis (Podsakoff, MacKenzie, Lee, \& Podsakoff, 2003). The results indicated that the maximal variance accounted for by a single factor is $34.341 \%$, less than the threshold of $50 \%$. Thus, common method bias is not a serious concern in our sample.

Table 2. Sample characteristics

\begin{tabular}{|c|c|c|c|}
\hline & Range & Number & Percentage $(\%)$ \\
\hline \multirow{9}{*}{$\begin{array}{l}\text { Business } \\
\text { industry }\end{array}$} & Electronics and information technology & 91 & 22.8 \\
\hline & Biological and medical technology & 17 & 4.3 \\
\hline & Aerospace technology & 9 & 2.3 \\
\hline & New material technology & 40 & 10.0 \\
\hline & High-tech service industry & 61 & 15.3 \\
\hline & $\begin{array}{l}\text { New energy and energy-saving technolo- } \\
\text { gies }\end{array}$ & 41 & 10.3 \\
\hline & Resources and environmental technology & 21 & 5.3 \\
\hline & Advanced manufacturing and automation & 38 & 9.5 \\
\hline & Others & 81 & 20.3 \\
\hline \multirow{4}{*}{$\begin{array}{l}\text { Organization } \\
\text { type }\end{array}$} & State-owned & 103 & 25.8 \\
\hline & Joint venture & 70 & 17.5 \\
\hline & Foreign & 49 & 12.3 \\
\hline & Private & 177 & 44.4 \\
\hline \multirow{5}{*}{$\begin{array}{l}\text { Organization } \\
\text { size (number } \\
\text { of employees) }\end{array}$} & $<20$ & 5 & 1.3 \\
\hline & $20-100$ & 69 & 17.3 \\
\hline & $101-300$ & 129 & 32.3 \\
\hline & $301-1000$ & 103 & 25.8 \\
\hline & $>1000$ & 93 & 23.3 \\
\hline \multirow{5}{*}{$\begin{array}{l}\text { Organization } \\
\text { age }\end{array}$} & $<3$ years & 5 & 1.3 \\
\hline & $3-10$ years & 84 & 21.1 \\
\hline & $11-20$ years & 202 & 50.6 \\
\hline & $21-50$ years & 79 & 19.8 \\
\hline & $>50$ years & 29 & 7.3 \\
\hline
\end{tabular}

Note: $\mathrm{n}=399$ 


\section{RESULTS}

\section{RELIABILITY AND VALIDITY ANALYSIS}

Before the hypothesis test, we used SPSS19.0 to test the reliability and validity of the measurements. The results (see Table 1) indicate that all of the items' loadings were above the recommended level of 0.70 . As Table 1 shows, the values of the Cronbach's alpha ranged from 0.713 to 0.788 , which indicated acceptable reliability. Table 3 shows that the composite reliability ranged from 0.821 to 0.864 , above the threshold of 0.70 , indicating that the items have good internal consistency. Further, the constructs' average variance extracted (AVE) scores ranged from 0.539 to 0.613 , above the acceptable level of 0.50 (Fornell \& Larcker, 1981), meaning that the variables have good convergent validity. Meanwhile, the square root of the AVE values exceed the correlations between the constructs, which indicates acceptable discriminant validity (Hair, Anderson, Tatham, \& William, 1998). These results indicate that the reliability and validity of our measurement instrument meet the requirements for model testing using structural equation modeling procedures.

Given that Internet capability was modeled as a second-order construct, we used AMOS21.0 to test whether the second-order construct can represent the first-order construct. According to Marsh and Hocevar (1985), whether the second-order construct is representative can be determined by calculating the target coefficient (first-order measurement model $\chi^{2} /$ second-order measurement model $\chi^{2}$ ). If the $\mathrm{T}$ value is closer to 1 , the second-order can replace the first-order CFA (confirmatory factor analysis), making the model more precise. The $T$ value of Internet capability is 0.99 , closer to 1 in this study. The fitness indexes of the second-order CFA of Internet capability indicate a good fit. Therefore, we take the results of the second-order CFA to analyze the structural model.

\section{Table 3. Results of correlation testing}

\begin{tabular}{|c|c|c|c|c|c|c|c|c|c|c|}
\hline Construct & Mean & SD & CR & AVE & IIC & IBC & IPC & SF & ID & KCP \\
\hline IIC & 3.5238 & 0.70737 & 0.848 & 0.583 & $\mathbf{0 . 7 6 4}$ & & & & & \\
\hline IBC & 3.7187 & 0.67387 & 0.849 & 0.585 & $0.668^{* *}$ & $\mathbf{0 . 7 6 5}$ & & & & \\
\hline IPC & 3.6955 & 0.69727 & 0.864 & 0.613 & $0.671^{* *}$ & $0.686^{* *}$ & $\mathbf{0 . 7 8 3}$ & & & \\
\hline SF & 3.6917 & 0.61808 & 0.854 & 0.540 & $0.516^{* *}$ & $0.540^{* *}$ & $0.533^{* *}$ & $\mathbf{0 . 7 3 5}$ & & \\
\hline ID & 3.5940 & 0.60640 & 0.821 & 0.604 & $0.496^{* *}$ & $0.430^{* *}$ & $0.454^{* *}$ & $0.412^{* *}$ & $\mathbf{0 . 7 3 4}$ & \\
\hline KCP & 3.4812 & .69566 & 0.823 & 0.539 & $0.528^{* *}$ & $0.544^{* *}$ & $0.522^{* *}$ & $0.524^{* *}$ & $0.615^{* *}$ & $\mathbf{0 . 7 7 7}$ \\
\hline
\end{tabular}

Note: Two-tailed tests were performed. ${ }^{*} \mathrm{p}<0.05 ;{ }^{* *} \mathrm{p}<0.01$. Diagonal elements are the square roots of average variance extracted. IIC represents Internet infrastructure capability, IBC represents Internet business spanning capability, IPC represents Internet proactive stance, SF represents strategic flexibility, ID represents informatization density, and KCP represents knowledge creation performance.

\section{STRUCTURAL MODEL}

A structural equation model was estimated to test the study's hypotheses. The analysis was conducted using Amos21.0 utilizing the maximum likelihood method. The model that was evaluated is shown in Figure 2 .

The $\chi^{2 / d f}$ value of the model is 1.721 , less than 3 . The GFI value is 0.928 , the AGFI value is 0.909 , the IFI value is 0.954 , and the CFI value is 0.983 - all greater than 0.9 . The NFI value is 0.896 , which is greater than 0.85 . The RMSEA value is 0.043 , which is less than 0.05. All the indices meet the requirements for a good model fit, indicating that the empirical data support our research model. In addition, except for $\mathrm{KCP} 3$, the loading values of the other items on their related variables are greater than 0.5. Although the factor loading of KCP3, seen in Figure 2, is low, it also exceeds the minimum requirement of 0.3 (Hou, Wen, \& Cheng, 2004). Considering that KCP3 is an important measure- 
ment of KCP, it is kept. The path value shows a positive and significant relationship between Internet capability and KCP, as $\mathrm{H} 1$ postulates $(\mathrm{H} 1: \beta=0.57, \mathrm{t}=5.479, \mathrm{p}<0.001)$. The path value provides support for $\mathrm{H} 2$ as well: There is a significantly positive relationship between Internet capability and strategic flexibility $(\mathrm{H} 2: \beta=0.74, \mathrm{t}=8.124, \mathrm{p}<0.001)$. The results also confirm a positive relationship between strategic flexibility and KCP, providing support for $\mathrm{H} 3(\mathrm{H} 3: \beta=0.38, \mathrm{t}=3.683, \mathrm{p}$ $<0.001)$.

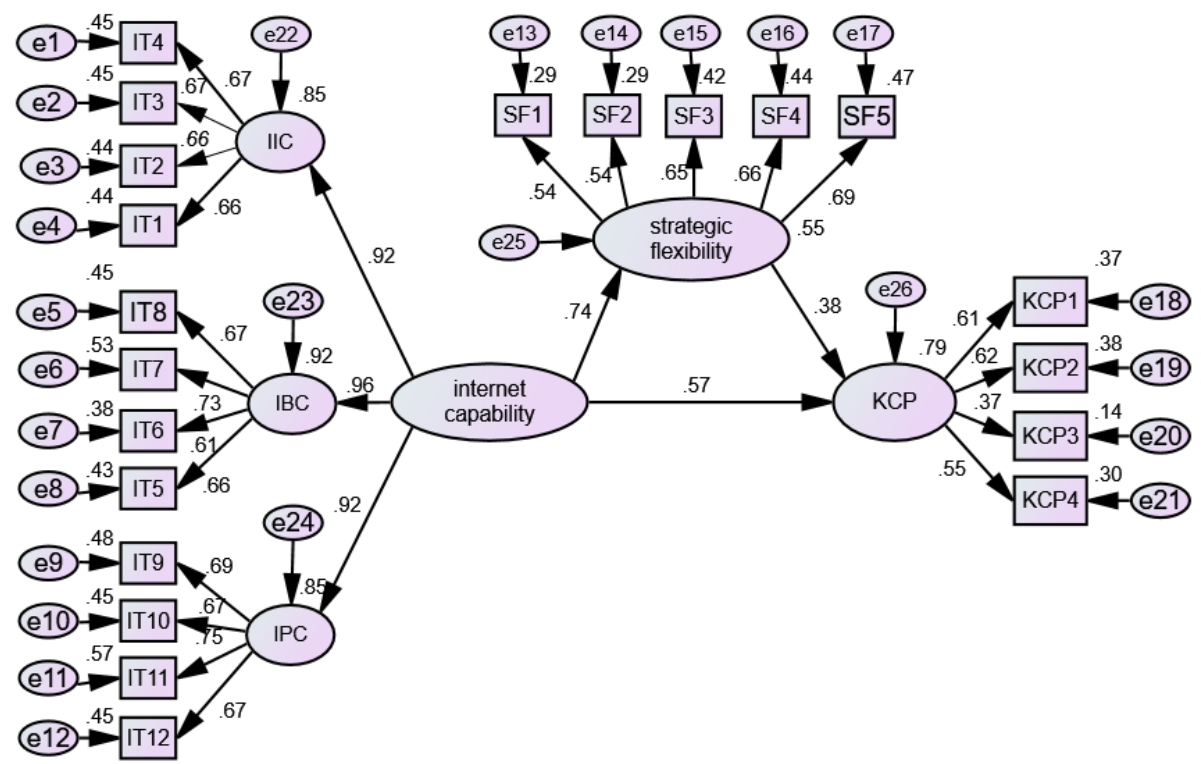

Figure 2. Amos results of the model with full sample

To test the mediating effect of strategic flexibility on the relationship between Internet capability and KCP (H4), we used Mackinnon, Fritz, Williams, and Lockwood's (2007) method. Using the bootstrap sampling method, 1000 simulations were performed, and the $95 \%$ confidence interval was selected. This method not only avoids estimation errors but also makes up for the limited sample size (Fritz \& Mackinnon, 2007). The schematic diagram of the mediating effect is presented in Figure 3. The test results are shown in Table 4 . The confidence interval of the strategic flexibility to be tested does not contain zero points, indicating that the null hypothesis that the mediating effect does not exist can be rejected. Thus, the mediating effect of strategic flexibility on the relationship between Internet capability and KCP is supported (H4).

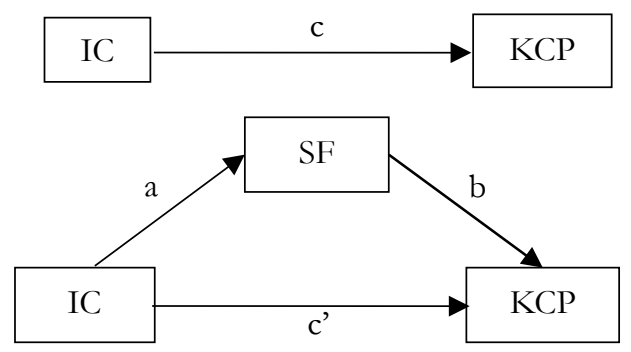

Figure 3. Schematic diagram of mediating effect

Note: IC represents Internet capability, SF represents strategic flexibility, and KCP represents knowledge creation performance. 
Table 4. Mediating effect test table

\begin{tabular}{|c|c|c|c|c|c|c|c|}
\hline \multirow{2}{*}{$\begin{array}{l}\text { Mediating } \\
\text { variable to be } \\
\text { tested }\end{array}$} & \multicolumn{2}{|c|}{ Path a } & \multicolumn{2}{|c|}{ Path b } & \multirow{2}{*}{$\begin{array}{l}\text { Correlation } \\
\text { coefficient } \\
\text { (c) }\end{array}$} & \multicolumn{2}{|c|}{ Confidence interval } \\
\hline & coefficient & $\begin{array}{l}\text { Std. } \\
\text { error }\end{array}$ & $\begin{array}{l}\text { coeffi- } \\
\text { cient }\end{array}$ & $\begin{array}{l}\text { Std. } \\
\text { error }\end{array}$ & & Lower & Upper \\
\hline $\begin{array}{l}\text { strategic } \\
\text { flexibility }\end{array}$ & 0.610 & 0.075 & 0.431 & 0.117 & 0.851 & 0.09750 & 0.48845 \\
\hline
\end{tabular}

Hierarchical regression analysis was conducted to test the moderating effect of informatization density on the relationship between Internet capability and KCP (H5). We first set Internet capability as the dependent variable, then added the control variable (model 1), independent variable (model 2), moderating variable (model 3), and the interaction between the independent variable and the moderating variable (model 4) to the regression equation. The results (see Table 5, Model 1) show that the control variables did not have a significant effect on KCP, indicating that firms should pay attention to KCP regardless of their size and IT specialty. Model 2 and Model 3 in Table 5 indicate that both Internet capability and informatization density have significantly positive effects on KCP. Model 4 shows that the interaction between informatization density and Internet capacity positively influences $\operatorname{KCP}(\beta=0.166, p<0.001)$, supporting hypothesis H5. In another words, informatization density strengthens the effect of Internet capability on KCP.

Following Aiken and West (1991), to further verify the moderating direction of informatization density, we investigate the difference in the influence of Internet capability on KCP under different informatization density levels. The results (see Figure 4) indicate that Internet capability has a positive impact on KCP regardless of whether informatization density is high or low. However, the slope of the straight line of the sample group under high informatization density is much larger than that of the control group under low informatization density. This means that, when the informatization density is high, the impact of Internet capability on KCP is stronger. This further confirms H5.

Table 5. Results of hierarchical analysis.

\begin{tabular}{|l|c|c|c|c|}
\hline Variable & Model 1 & Model 2 & Model 3 & Model 4 \\
\hline Control variables & & & & \\
\hline Organization age & 0.044 & 0.041 & 0.039 & 0.032 \\
\hline Organization size & -0.002 & -0.006 & 0.021 & 0.014 \\
\hline IT expertise & $0.145^{*}$ & -0.037 & -0.045 & -0.034 \\
\hline IS age & 0.107 & 0.028 & 0.028 & 0.031 \\
\hline Main effects & & & & \\
\hline IC & & $0.607 * * *$ & $0.423^{* * *}$ & $0.455^{* * *}$ \\
\hline ID & & & $0.244^{* * *}$ & $0.282^{* * *}$ \\
\hline Moderation effects & & & & \\
\hline IC $*$ ID & & & & $0.166^{* * *}$ \\
\hline R2 & 0.038 & $0 . .365$ & 0.389 & 0.412 \\
\hline Adj. R2 & 0.028 & 0.357 & 0.380 & 0.401 \\
\hline F & 3.864 & 45.134 & 41.656 & 39.103 \\
\hline
\end{tabular}

Note: ${ }^{*} \mathrm{p}<0.05 ;{ }^{* *} \mathrm{p}<0.01 ;{ }^{* * *} \mathrm{p}<0.01$. IC represents Internet capability, ID represents informatization density. 


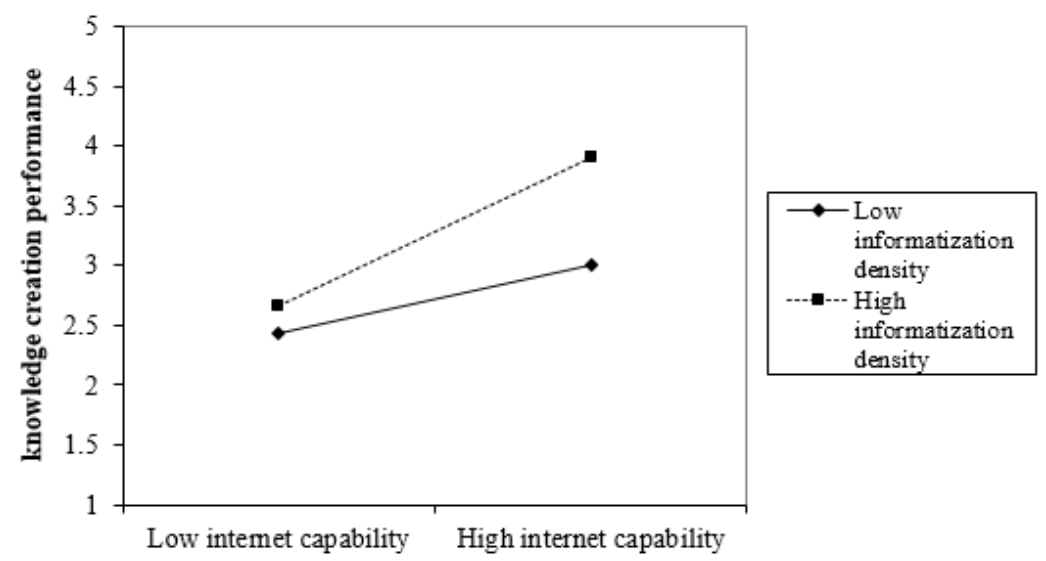

Figure 4. Moderating effect of informatization density

\section{DISCUSSION}

\section{IMPLICATIONS FOR THEORY}

This study offers several theoretical contributions. First, different degrees of mastery and use of Internet technology lead to different Internet capability levels for firms. Differences in this competency will affect organizational performance, competitive advantage, and customer value realization (Bhatt, 2000; Celuch et al., 2007; Y. Chen et al., 2014; Prajogo, 2016). However, the impact of this difference on KCP is not a cause for concern. This study integrates Internet capability, strategic flexibility, and $\mathrm{KCP}$ into the same framework, thus expanding the research perspective on knowledge creation and focusing on the further achievement of KCP. We also placed the question in the Internet context, systematically exploring effective ways of enhancing KCP. On the theoretical level, this study enriches the exploration of KCP in the Internet context and deepens the research on the internal mechanism by which Internet capability influences KCP. Second, most studies discuss the moderating role of external factors such as environmental uncertainty and industry characteristics (Bhatt, 2000; Wade \& Hulland, 2004) and rarely consider the potential moderating role of informatization density. This study understands that informatization density in the Internet context may have an impact and adds it to the KCP theory framework. Informatization density is found to play a moderating role in the relationship between Internet capability and KCP. This highlights the important role of informatization density in the Internet context and expands the research on the impact of external factors on the internal mechanism.

\section{IMPLICATIONS FOR PRACTICE}

The findings of this study have several implications for management practices. First, business managers should recognize the opportunity created by the rapid development of the Internet. Internet capability in the network environment is an important resource that firms can use to enhance their strategic flexibility and promote KCP. Enhancing Internet capability on all levels is necessary for firms. This requires businesses to not only enhance their Internet infrastructure application but also adopt a proactive approach to understand the potential value of Internet capability. Firms should also effectively combine Internet construction with their business strategy.

Second, firms should pay attention to the direct and indirect effects of strategic flexibility on KCP. Strategic flexibility reflects not only the organization's response to changes in the external environment but also the initiative it takes to shape the environment. The research often neglects the initiative characteristic of strategic flexibility (Fan \& Wu, 2014; Narver, Slater, \& Maclachlan, 2004). Inter- 
net capability can allow the organization to predict environmental changes and then create an environment favorable for development. It also helps organizations to acquire knowledge from suppliers, competitors, and customers and to coordinate internal and external resources to respond to environmental changes in a timely way (Celuch et al., 2007). This shows us that improving their strategic flexibility is crucial to firms' achievement of KCP in the Internet context. Firms should combine the initiative and passive aspects of strategic flexibility and formulate strategies for development based on the dual characteristics.

Third, the impact of informatization density on the relationship between Internet capability and KCP is quite different. Firms should pay attention to the potential role of informatization density in the Internet context. Depending on the application of the informatization of the industrial chain, firms should correspondingly enhance their Internet capability to achieve superior KCP. In 2015, Chinese Premier Li Keqiang stated in his "Government Work Report" (W. Li \& Sun, 2016) that the "Internet +" action plan was formulated to promote the integration of mobile Internet, cloud computing, big data, and the Internet of things with modern manufacturing. "Made in China 2025" emphasizes "advancing the deep integration of informatization and industrialization, vigorously promoting the breakthrough development in key areas, and focusing on a new generation of information technology industry." The important role of the Chinese government in the informatization construction of the industrial chain has been recognized by both the business and research communities (B. Li \& Liang, 2017; K. W. Li et al., 2015; Liu, 2016). The findings of this study suggest that the Chinese government and trade associations should guide and encourage the informatization construction of all links in the industrial chain to ensure smooth access to channels of information, sharing, exchange, and innovation among firms.

\section{CONCLUSION}

This study integrates the RBV, KBV, and dynamic capability theory to examine the mechanism of Internet capability driving KCP. Informatization density is observed to be a moderator of the relationship between Internet capability and KCP. This finding extends our understanding of the influence of external factors on the internal mechanism. Moreover, Internet capability is found to directly impact strategic flexibility, yet it affects KCP both directly and indirectly through strategic flexibility, which confirms that strategic flexibility is a partial mediator in the relationship between Internet capability and KCP. These findings enrich the exploration of the achievement of KCP in the Internet context and deepens the research on the internal mechanism of Internet capability affecting KCP. These findings show that considering the two important factors of strategic flexibility and informatization density allows us to explain the KCP mechanism driven by Internet capability.

Our study has several limitations. First, it studies Internet capability as a second-order construct, mainly investigating the influence of Internet capability on an integration level. It is necessary to further consider the difference of the first-order dimensions of Internet capability. Second, the sample firms in this study are limited to China. It remains unknown whether the findings of this study can be extended to other countries given the national differences in social, technical, and economic environments. Future research can collect data from various countries and regions to test our research model. Third, this study is cross-sectional, which may lead to a temporary causality. Longitudinal studies could be conducted to increase the robustness of our conclusions.

\section{ACKNOWLEDGMENTS}

This work was supported by the National Social Science Foundation of China [15FGL005], the National Natural Science Foundation of China [71403052, 71403055], and the Social Science Planning 
The Mechanism of Internet Capability Driving Knowledge Creation Performance

Project of Fujian Province of China [FJ2016C030]. The authors thank to the honorable editor of IJIKM for their constructive comments and suggestions that have contributed to improve this manuscript

\section{REFERENCES}

Aiken, L. S., \& West, S. G. (1991). Multiple regression: Testing and interpreting interactions. Newbury Park, CA: Sage.

Ansoff, H. I. (1965). Corporate strategy: An analytic approach to business policy for growth and expansion. New York: McGraw-Hill.

Bayo-Moriones, A., Billón, M., \& Lera-López, F. (2013). Perceived performance effects of ICT in manufacturing SMEs. Industrial Management \& Data Systems, 113 (1), 117-135. https://doi.org/10.1108/02635571311289700

Becchetti, L., Bedoya, D. A. L., \& Paganetto, L. (2003). ICT investment, productivity and efficiency: Evidence at firm level using a stochastic frontier approach. Journal of Productivity Analysis, 20(2), 143-167. https://doi.org/10.1023/A:1025128121853

Bharadwaj, A. S. (2000). A resource-based perspective on information technology capability and firm performance: An empirical investigation. MIS Quarterly, 24(1), 169-196. https://doi.org/10.2307/3250983

Bhatt, G. D. (2000). Exploring the relationship between information technology, infrastructure and business process re-engineering. Business Process Management Journal, 6(2), 139-163. https://doi.org/10.1108/14637150010324085

Bierly, P. E., \& Chakrabarti, A. K. (1996). Technological learning, strategic flexibility, and new product development in the pharmaceutical industry. IEEE Transactions on Engineering Management, 43(4), 368-380. https://doi.org/10.1109/17.543979

Cai, Y. Z. (2015). Research commercialization: Content, boundary as well as statistics and measuring. Studies in Science of Science, 33(1), 37-44.

Ceccagnoli, M., \& Hicks, D. (2013). Complementary assets and the choice of organizational governance: Empirical evidence from a large sample of US technology-based firms. IEEE Transactions on Engineering Management, 60(1), 99-112. https://doi.org/10.1109/TEM.2012.2201159

Celuch, K., Murphy, G. B., \& Callaway, S. K. (2007). More bang for your buck: Small firms and the importance of aligned information technology capabilities and strategic flexibility. Journal of High Technology Management Research, 17(2), 187-197. https://doi.org/10.1016/i.hitech.2006.11.006

Chen, C. J., Chang, C. C., \& Hung, S. W. (2011). Influences of technological attributes and environmental factors on technology commercialization. Journal of Business Ethics, 104(4), 525-535. https://doi.org/10.1007/s10551-011-0926-6

Chen, H., \& Hou. J. (2017). The operation performance of patent innovation in knowledge-intensive manufacturing industry. Systems Engineering-Theory \& Practice, 37(7), 1709-1719.

Chen, Y., Wang, Y., Nevo, S., Jin, J., Wang, L., \& Chow, W. S. (2014). IT capability and organizational performance: The roles of business process agility and environmental factors. European Journal of Information Systems, 23(3), 326-342. https://doi.org/10.1057/ejis.2013.4

Cingöz, A., \& Akdoğan, A. A. (2013). Strategic flexibility, environmental dynamism, and innovation performance: An empirical study. Procedia-Social and Behavioral Sciences, 99, 582-589. https://doi.org/10.1016/j.sbspro.2013.10.528

Evans, J. S. (1991). Strategic flexibility for high technology manoeuvres: A conceptual framework. Journal of Management Studies, 28(1), 69-89. https://doi.org/10.1111/j.1467-6486.1991.tb00271.x

Fan Z. G., \& Wu X. B. (2014). Empirical research on strategic flexibility and innovation performance under dynamic environment. Science Research Management, 35(1), 1-8. 
Fornell, C., \& Larcker, D. F. (1981). Evaluating structural equation models with unobservable variables and measurement error. Journal of Marketing Research, 18(1), 39-50. https://doi.org/10.2307/3151312

Fritz, M. S., \& Mackinnon, D. P. (2007). Required sample size to detect the mediated effect. Psychological Science, 18(3), 233-239.https://doi.org/10.1111/j.1467-9280.2007.01882.x

Glavas, C., \& Mathews, S. (2014). How international entrepreneurship characteristics influence internet capabilities for the international business processes of the firm. International Business Review, 23(1), 228-245. https://doi.org/10.1016/j.ibusrev.2013.04.001

Gulati, R., Nohria, N., \& Zaheer, A. (2000). Strategic networks. Strategic Management Journal, 21(3), 203-215. https://doi.org/10.1002/(SICI) 1097-0266(200003)21:3<203::AID-SMJ102>3.0.CO;2-K

Hatch, J., \& Zweig, J. (2001). Strategic flexibility: The key to growth. Ivey Business Journal, 65(4), 44-47.

Hair, J. F., Anderson, R. E., Tatham, R. L., \& William, C. (1998). Multivariate data analysis. Upper Saddle River, NJ, US: Prentice Hall.

Hou, J. T., Wen Z. L., \& Cheng Z. J. (2004). Structural equation model and its application. Educational Science Press.

Jiang, X., Mu, W., \& Zhou, M. (2017). How can firms achieve successful technology commercialization? Studies in Science of Science, 35(7), 1032-1042.

Johnson, J. L., Lee, P. W., Saini, A., \& Grohmann, B. (2003). Market-focused strategic flexibility: Conceptual advances and an integrative model. Journal of the Academy of Marketing Science, 31(1), 74-89. https://doi.org/10.1177/0092070302238603

Joshi, K. D., Chi, L., Datta A., \& Han, S. (2010).Changing the competitive landscape: Continuous innovation through IT-enabled knowledge capabilities. Information Systems Research, 21(3), 472-495. https://doi.org/10.1287/isre.1100.0298

Kane, G. C., \& Alavi, M. (2007). Information technology and organizational learning: An investigation of exploration and exploitation processes. Organization Science, 18(5), 796-812. https://doi.org/10.1287/orsc.1070.0286

Kao, S. C., \& Wu, C. H. (2016).The role of creation mode and social networking mode in knowledge creation performance: mediation effect of creation process. Information \& Management, 53(6), 803-816. https://doi.org/10.1016/j.im.2016.03.002

Lee, O. K. D., \& Lim, K. H. (2005). Redefining organizational information technology-based capabilities with an integrative framework for multiple levels of analysis. In Proceedings of the Pacific Asia Conference on Information Systems (PACIS 2005), 94.

Liao, J., Kickul, J. R., \& Ma, H. (2009). Organizational dynamic capability and innovation: An empirical examination of internet firms. Journal of Small Business Management, 47(3), 263-286. https://doi.org/10.1111/j.1540-627X.2009.00271.x

Li, B., \& Liang, S. L. (2017). ICT, informatization density and regional industry growth--An empirical study based on industrial data in China. Journal of Shanxi University of Finance and Economics, 39(9), 58-71.

Li, K. W., Shao, W. B., \& Wang Y. J. (2015). Information density, information infrastructure and enterprise export performance--Based on the theoretical and empirical analysis of enterprise heterogeneity. Management World, 4, 52-65.

Li, M., Liu, H., \& Zhou, J. (2018). G-SECI model-based knowledge creation for CoPS innovation: The role of grey knowledge. Journal of Knowledge Management, 22(4), 887-911. https://doi.org/10.1108/JKM-10-2016$\underline{0458}$

Li, W., \& Sun, F. M. (2016). The enlightenment of German "Industry 4.0" on China's "Internet +". China Management Informationization, 19(01), 162-164. 
Li, Y., Guo, H., Liu, Y., \& Li, M. (2008). Incentive mechanisms, entrepreneurial orientation, and technology commercialization: Evidence from China's transitional economy. Journal of Product Innovation Management, 25(1), 63-78. https://doi.org/10.1111/j.1540-5885.2007.00283.x

Lin, Y. Q., \& Zhao, S. M. (2013). A study of network-building HR practices for TMT, strategic flexibility and firm performance: The moderating role of environmental uncertainty. Nankai Business Review, 16(2), 4-15.

Liu J. (2016). Informationized density and Chinese firms export decision: Based on the perspective of product value chain. Journal of International Trade, 6, 39-49.

Lu, Y., \& Ramamurthy, K. (2011). Understanding the link between information technology capability and organizational agility: An empirical examination. MIS Quarterly, 35(4), 931-954. https://doi.org/10.2307/41409967

Mackinnon, D. P., Fritz, M. S., Williams, J., \& Lockwood, C. M. (2007). Distribution of the product confidence limits for the indirect effect: program prodclin. Behavior Research Methods, 39(3), 384-389. https://doi.org/10.3758/BF03193007

Mao, H., Liu, S., \& Zhang, J. (2015). How the effects of IT and knowledge capability on organizational agility are contingent on environmental uncertainty and information intensity. Information Development, 31(4), 358382. https://doi.org/10.1177/0266666913518059

Mao, H., Liu, S., Zhang, J., \& Deng, Z. (2016). Information technology resource, knowledge management capability, and competitive advantage. International Journal of Information Management, 36(6), 1062-1074. https://doi.org/10.1016/j.ijinfomgt.2016.07.001

Marsh, H. W., \& Hocevar, D. (1985). Application of confirmatory factor analysis to the study of self-concept: First-and higher order factor models and their invariance across groups. Psychological Bulletin, 97(3), 562-582. https://doi.org/10.1037/0033-2909.97.3.562

Martin-de Castro, G., Lopez-Saez, P., \& Delgado-Verde, M. (2011). Towards a knowledge-based view of firm innovation. Theory and empirical research. Journal of Knowledge Management, 15(6), 871-874. https://doi.org/10.1108/13673271111179253

Narver, J. C., Slater, S. F., \& Maclachlan, D. L. (2004). Responsive and proactive market orientation and newproduct success. Journal of Product Innovation Management, 21(5), 334-347. https://doi.org/10.1111/j.0737$\underline{6782.2004 .00086 . x}$

Park, T., \& Ryu, D. (2015). Drivers of technology commercialization and performance in SMEs: The moderating effect of environmental dynamism. Management Decision, 53(2), 338-353. https://doi.org/10.1108/MD$\underline{03-2014-0143}$

Podsakoff, P. M., MacKenzie, S. B., Lee, J. Y., \& Podsakoff, N. P. (2003). Common method biases in behavioral research: A critical review of the literature and recommended remedies. Journal of Applied Psychology, 88(5), 879. https://doi.org/10.1037/0021-9010.88.5.879

Prajogo, D. I. (2016). The strategic fit between innovation strategies and business environment in delivering business performance. International Journal of Production Economics, 171, 241-249. https://doi.org/10.1016/i.ijpe.2015.07.037

Ross, J. W., Beath, C. M., \& Goodhue, D. L. (1996). Develop long-term competitiveness through IT assets. Sloan Management Review, 38(2), 31-42.

Sambamurthy, V., Bharadwaj, A., \& Grover, V. (2003). Shaping agility through digital options: Reconceptualizing the role of information technology in contemporary firms. MIS Quarterly, 237-263. https://doi.org/10.2307/30036530

Schneckenberg, D., Truong, Y., \& Mazloomi, H. (2015). Microfoundations of innovative capabilities: The leverage of collaborative technologies on organizational learning and knowledge management in a multinational corporation. Technological Forecasting and Social Change, 100, 356-368.

https://doi.org/10.1016/i.techfore.2015.08.008 
Schneider, S., \& Spieth, P. (2014). Business model innovation and strategic flexibility: Insights from an experimental research design. International Journal of Innovation Management, 18(6), 1440009. https://doi.org/10.1142/S136391961440009X

Teece, D. J. (2007). Explicating dynamic capabilities: the nature and microfoundations of (sustainable) enterprise performance. Strategic Management Journal, 28(13), 1319-1350. https://doi.org/10.1002/smi.640

Umanath, N. S. (2003). The concept of contingency beyond "it depends": Illustrations from is research stream. Information \& Management, 40(6), 551-562. https://doi.org/10.1016/S0378-7206(02)00080-0

Volkoff, O., Strong, D., \& Elmes, M. (2007). Technological embeddedness and organizational change. Organization Science, 18(5), 832-848. https://doi.org/10.1287/orsc.1070.0288

Wade, M., \& Hulland, J. (2004). Review: The resource-based view and information systems research: Review, extension, and suggestions for future research. MIS Quarterly, 28 (1), 107-142.

Wang, T., \& Jia, R.(2011). An empirical study on the effect of strategic flexibility on enterprise performance. Chinese Journal of Management, 3, 78-91.

Wang, Y. J., Xie, W. H., \& Lan, H. L. (2012). IT capability and strategic flexibility: The mediating effects of exploratory and exploitative learning. Economic Management, 34(11), 64-73.

Weill, P., Subramani, M., \& Broadbent, M. (2002). Building IT infrastructure for strategic agility. MIT Sloan Management Review, 44(1), 57-65.

Yang, M., \& Wang, R. X. (2017). System paradox information density of product chain and the decision of R\&D alliance. Studies in Science of Science, 35(7), 995-1003.

Yu, W., Jacobs, M. A., Chavez, R.., \& Feng, M. (2017). The impacts of IT capability and marketing capability on supply chain integration: A resource-based perspective. International Journal of Production Research, 55(14), 4196-4211. https://doi.org/10.1080/00207543.2016.1275874

Zhang, H. B. (2015). Impact of knowledge transfer on innovative performance of the alliance enterprises by taking strategic flexibility as a mediating factor. Science Research Management, 36(7), 1-9.

Zhang, M. J. (2005). Information systems, strategic flexibility and firm performance: an empirical investigation. Journal of Engineering \& Technology Management, 22(3), 163-184.

https://doi.org/10.1016/i.jengtecman.2005.06.003

\section{BIOGRAPHIES}

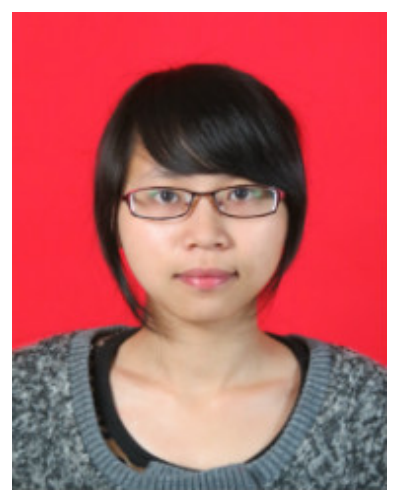

Caiyun Zhuang obtained her Master degree of Management from Fuzhou University, China. She is now a $\mathrm{PhD}$ student major in Management Science and Engineering at Fuzhou University. Her research interests include: knowledge creation; knowledge management; technology innovation; management of science and technology, industrial technology development. 


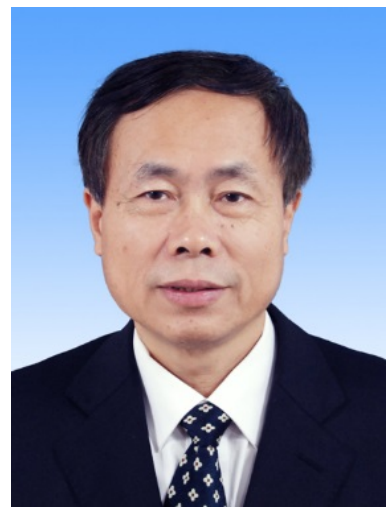

Guohong Chen is a Professor at School of Economics and Management of Fuzhou University, China. He obtained his Bachelor degree in Fuzhou University, Master degree in Zhejiang University and $\mathrm{PhD}$ degree in $\mathrm{Fu}-$ dan University. He is also a government consultant and a major member of several related professional societies. His research interests include technology innovation, technology economy, technology management and policy, knowledge management, evaluation theory、methods and applications.

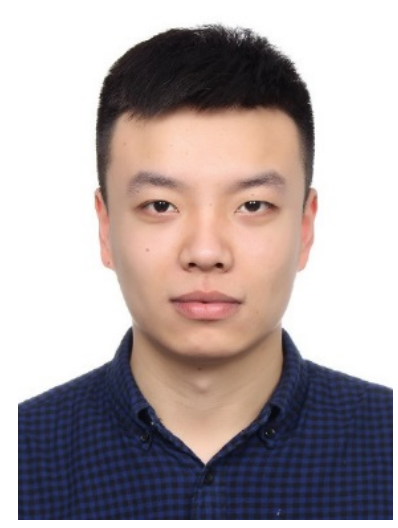

Jian Hou obtained his Master degree of Management from Harbin Engineering University, China. He is now a $\mathrm{PhD}$ student major in Management Science and Engineering at Harbin Engineering University. His research interests include: Regional and industrial technological innovation (patent output, intellectual property, and knowledge management), open innovation, paradigm and effect mechanism of technological innovation, technology transfer, evaluation of technological innovation (innovation efficiency, innovation operation, technology transformation).

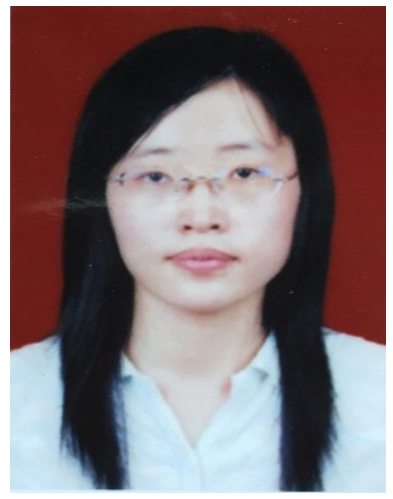

Juan Liang is a associate professor at School of Business Administration of Fujian Jiangxia University, China. She acquired her PhD from Fuzhou University. Her research interests include knowledge management, technology innovation, industrial technology development. 